\title{
Reactive oxygen species and fibrosis: further evidence of a significant liaison
}

\author{
Kati Richter $^{1} \cdot$ Thomas Kietzmann $^{1}$ \\ Received: 21 March 2016 / Accepted: 2 June 2016 / Published online: 27 June 2016 \\ (C) The Author(s) 2016. This article is published with open access at Springerlink.com
}

\begin{abstract}
Age-related diseases such as obesity, diabetes, nonalcoholic fatty liver disease, chronic kidney disease and cardiomyopathy are frequently associated with fibrosis. Work within the last decade has improved our understanding of the pathophysiological mechanisms contributing to fibrosis development. In particular, oxidative stress and the antioxidant system appear to be crucial modulators of processes such as transforming growth factor- $\beta 1$ (TGF- $\beta 1$ ) signalling, metabolic homeostasis and chronic low-grade inflammation, all of which play important roles in fibrosis development and persistence. In the current review, we discuss the connections between reactive oxygen species, antioxidant enzymes and TGF- $\beta 1$ signalling, together with functional consequences, reflecting a concept of redox-fibrosis that can be targeted in future therapies.
\end{abstract}

Keywords Reactive oxygen species (ROS) - Antioxidants . Antioxidative enzymes $\cdot$ Matrix $\cdot$ Fibrosis

\section{Introduction}

Age-related diseases and their associated complications such as organ fibrosis are considered to represent a major health problem worldwide. Fibrosis can be described as an

The work of the authors was supported by grants from the Academy of Finland, CIMO, Jane and Aatos Erkko Foundation and the European Cooperation in Science and Technology organization (COST Action BM1203/EU-ROS).

\section{Thomas Kietzmann}

tkietzm@gwdg.de

1 Faculty of Biochemistry and Molecular Medicine and Biocenter Oulu, University of Oulu, Aapistie 7A, FI-90230 Oulu, Finland irreversible non-physiological scarring process usually occurring as a consequence of inflammation or other injury in which an excessive appearance of extracellular matrix (ECM) contributes to further tissue damage. Fibrosis is not limited to any specific organ and can have multiple causes. For example, hepatic fibrosis can result from infection, alcohol, drugs or morbid obesity. Pulmonary fibrosis can be the result of radiation exposure or genetic alterations (e.g., cystic fibrosis) or it can be idiopathic. The various types of cardiac fibrosis range from congenital or idiopathic (e.g., endomyocardial fibrosis) to ischaemic. Retroperitoneal fibrosis and peritoneal fibrosis may result from therapies (the former has been associated with autoimmunity, malignancy and some forms of medication, such as $\beta$-blockers; the latter might be a complication of peritoneal dialysis). Many disorders, e.g., acquired, congenital, iatrogenic or allergic, culminate in renal fibrosis. Moreover, fibrosis of the skin is often caused by iatrogenic drug-related (eosinophilia-myalgia syndrome) or environmental (polyvinyl chloride, toxic/denatured "Spanish" rapeseed oil) factors (Boin and Hummers 2008). Thus, we need to understand the pathophysiology of fibrosis not only in the context of the wide spectrum of complications related to contemporary therapies and drugs but also as a consequence of chronic disease.

Although some organ-specific aspects of fibrosis are known, fibrosis is not restricted to any particular organ and is found to occur in all organs and tumour tissues (Dvorak et al. 1984; Dvorak 1986; Kalluri and Zeisberg 2006; Rockey et al. 2015) suggesting the existence of a common pathogenetic pattern in which fibroblasts are primary ECM producers. Those fibroblasts possessing an increased synthetic capacity in fibrosis are called "myofibroblasts" or "activated fibroblasts" (Hecker et al. 2011). Myofibroblasts appear to be derived either from tissue-resident fibroblasts, bone-marrowderived fibrocytes (Bucala et al. 1994) or vascular smooth 
muscle cells and pericytes shed from vessels (Lin et al. 2008; Ronnov-Jessen et al. 1995). In addition, endothelial cells that have undergone endothelial-to-mesenchymal transition (Zeisberg et al. 2007) and epithelial cells after epithelial-tomesenchymal transition (Strutz et al. 1995) might give rise to fibrotic ECM production (Fig. 1).

A common pattern is also visible, macroscopically and microscopically. In addition to being hard and non-elastic, fibrotic tissue is also pale, reflecting injured parenchyma with an excess presence of fibrillar ECM and fibroblasts and a lack of capillaries. Further, a mononuclear infiltrate is also usually observed (Kalluri and Zeisberg 2006). In addition, recent findings at a more molecular level suggest that disturbances in the formation and degradation of reactive oxygen species (ROS) are a crucial part of the common fibrotic pathway. These findings have fed the concept of "redox-fibrosis", which will be discussed in the current review together with its therapeutic potential.

\section{Fibrosis, ROS and oxidative stress}

Lost parenchyma after tissue injury is usually replaced, because of the ability of parenchymal cells to regenerate. However, the opportunity to regenerate usually becomes unavailable upon repetitive insults associated with chronic inflammation, the secretion of chemokines and the release of profibrotic metabolites, among them, ROS. Further, the production of ROS and the concomitant oxidative stress also contribute to the synthesis and activation of various cytokines and growth factors (Barnes and Gorin 2011; Babalola et al. 2014; Paik et al. 2014) indicating common feed-forward and feedback mechanisms (Fig. 2).

The link between ROS and oxidative stress became particularly evident from investigations showing that increased levels of hydrogen peroxide and oxidative stress markers such as 8-isoprostane were to be found in exhalants and in the urine of patients with lung fibrosis, respectively (Dekhuijzen et al. 1996; Pratico et al. 1998). In addition, enhanced levels of the lipid peroxidation marker 4-hydroxy-2'-nonenal (Seki et al. 2005) were found in biopsy specimens from patients with liver fibrosis. Moreover, ROS were proposed to be crucial for the development of asbestosis and silicosis, since nitrotyrosine adducts and the oxidative DNA damage indicator 8-hydroxy-2'-deoxyguanosine were found in those patients (Pilger et al. 2000; Pelclova et al. 2008). In addition, ROS and oxidative stress appear to be important in renal fibrosis (Ha and Lee 2003; Djamali et al. 2009) and tissue repair/ remodelling after myocardial infarction (Murdoch et al. 2006; Sirker et al. 2007; Aragno et al. 2008).

\section{Sources and sites of ROS production}

Ultraviolet light, ionizing radiation, toxic chemicals and drugs are well-known inducers of fibrosis and of ROS formation in a non-enzymatic manner in vivo (Fig. 2). Intracellularly, most
Fig. 1 Activated fibroblasts are key players in the fibrotic process and extracellular matrix $(E C M)$ production. Fibroblasts involved in fibrosis can be derived from vascular smooth muscle cells, pericytes, fibrocytes, endo- and epithelial cells or resident fibroblasts. Depending on their origin, these cells undergo proliferation, differentiation and endothelial/epithelial-tomesenchymal transition (EndoMT/EMT) and the emerging myofibroblasts/activated fibroblasts excessively synthesize and secrete ECM proteins that contribute to fibrosis

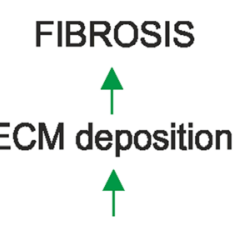

\section{Synthesis of matrix proteins}

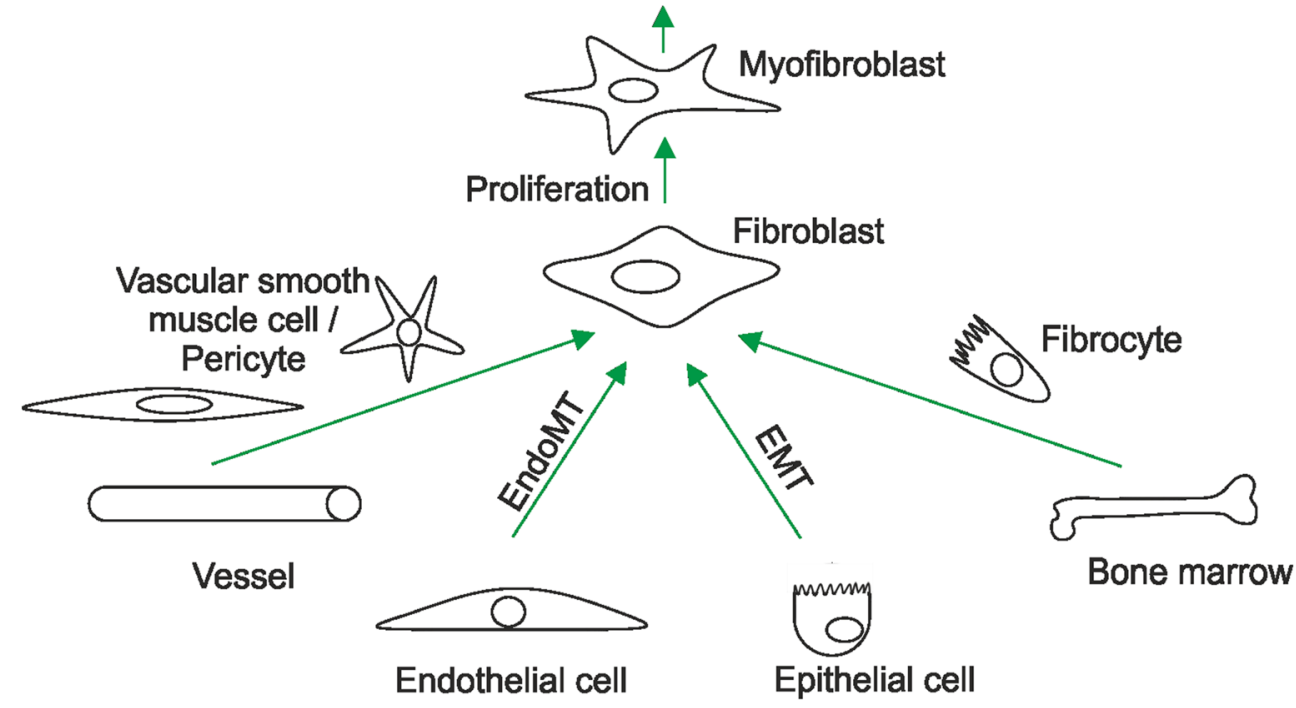




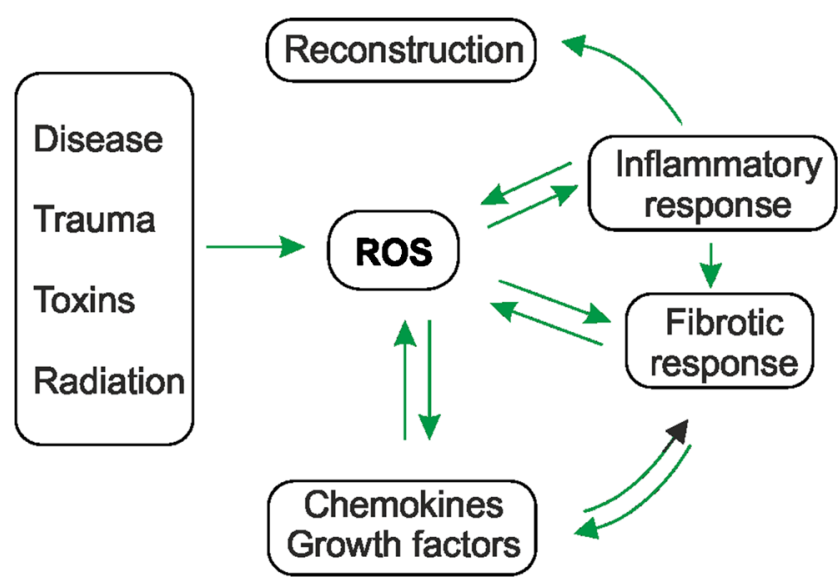

Fig. 2 Reactive oxygen species $(R O S)$ contribute to fibrosis via various feed-forward and feedback loops. Insults resulting from infectious diseases, trauma, toxins, drugs and radiation (UV, ionizing) induce ROS generation. Subsequently, ROS contribute to the fibrotic process either directly or indirectly via enhanced inflammation. Fibrosis and the inflammation itself might feedback into the pathway and further increase ROS formation or stimulate the production of cytokines and growth factors. The last two mentioned substances can also contribute to ROS formation. In a non-fibrotic process, inflammation and ROS formation end in tissue regeneration

ROS are by-products of the mitochondrial electron transport chain. In addition, ROS can be produced more specifically by various enzymes, among them members of the cytochrome P450 family, xanthine oxidoreductase, cyclo- and lipoxygenases, several peroxisomal oxidases and NADPH oxidases (NOX; for a review, see Samoylenko et al. 2013).

Of the ROS-producing enzymes, NOX appear to have a key role during fibrosis (Brown and Griendling 2009; O'Neill et al. 2015). The classic NOX from phagocytes forms a multiprotein complex, whereas the transmembrane proteins NOX2 (also known as gp91phox) and p22phox form the catalytic core for $\mathrm{O}_{2}^{-} \cdot$ production, which rapidly dismutates to hydrogen peroxide (Deffert et al. 2014; Nauseef 2014). In addition to NOX2, further NOX proteins designated NOX15 and the more distantly related DUOX $1 / 2$ proteins (Brown and Griendling 2009; O'Neill et al. 2015) have been identified. Although the expression of NOX2 is most evident in polymorphonuclear cells, macrophages and endothelial cells, its expression has also been verified in other cell types including cells from the central nervous system, smooth muscle cells, fibroblasts, cardiomyocytes, skeletal muscle, hepatocytes and haematopoietic stem cells (Gorlach et al. 2015). NOX1 is also present in the plasma membranes of various cell types (Brown and Griendling 2009; Aguirre and Lambeth 2010; Badid et al. 2010), whereas NOX3, NOX4 and NOX5 appear to have different subcellular locations and cell-specific expression patterns (for a review, see Gorlach et al. 2015). NOX3 is found in fetal tissues, the inner ear and lung endothelium and in HepG2 and RAW264.7 cells. NOX4 is widely expressed at very high levels in kidney, whereas NOX5 is more abundant in lymph nodes, spleen, prostate and testis and in endothelial and smooth muscle cells. Both NOX types appear to be mainly localized in the endoplasmic reticulum (for a review, see Gorlach et al. 2015). In general, NOX and DUOX activities, except those of NOX4, are controlled by regulatory subunits. Among these are the NOX2 cytosolic subunits p40phox, p47phox and p67phox, their NOX1- and NOX3-regulating homologues NOXO1 and NOXA1 and the DUOX1/2 regulators DUOXA1 and 2 plus the GTPase Rac. In addition, the activation of NOX5 and DUOX1/2 is dependent on calcium signalling (BelAiba et al. 2007). NOX4 activity seems to be independent of regulatory subunits.

NOX-derived ROS have been found to be associated with fibrosis in several organs such as lung (Hecker et al. 2009), heart (Cucoranu et al. 2005), kidney (Sedeek et al. 2013), pancreas (Masamune et al. 2007) and liver (De Minicis and Brenner 2007; Cui et al. 2011; Paik et al. 2011). Of the NOX proteins, NOX4 is unique in that its activity is mainly regulated via its expression levels and that it does not require further regulatory subunits except for its dimerization partner p22phox (Petry et al. 2006; Paik et al. 2014). Moreover, NOX4 has been closely linked to endothelial cell dysfunction and hypoxia, conditions known to promote its expression (Bernard et al. 2014). Thus, compared with the more complex regulation of the other NOX enzymes, NOX4 might have a more critical role in ROS production under conditions promoting fibrosis.

\section{ROS and TGF- $\beta$ are interlinked by feed-forward and feedback mechanisms}

The onset and progression of fibrosis appear to involve not only ROS formation but also the synthesis and secretion of various growth factors and chemokines. Cytokines of the transforming growth factor- $\beta$ (TGF- $\beta$ ) family crucially participate in the fibrotic process in most if not all organs (Akram et al. 2013; Aravinthan et al. 2013; Rudolph et al. 2000). So far, three TGF- $\beta$ isoforms (called TGF- $\beta 1$, TGF- $\beta 2$ and TGF- $\beta 3$ ) have been identified; before these isoforms were discovered, TGF- $\beta$ referred only to TGF- $\beta 1$. Although primarily linked to fibrosis, TGF- $\beta 1$ also seems to be important in the pathogenesis of other diseases such as Marfan syndrome, Parkinson's disease, various forms of cancer and diabetes (for reviews, see Leask and Abraham 2004; Leask et al. 2004; Zheng 2009). Importantly, the production of TGF- $\beta 1$ is increased in all fibrotic tissues. Further, it can induce collagen expression in fibroblast cell cultures of various origins (Romanelli et al. 1997; Kim et al. 1998; Abraham et al. 2000; Hogaboam et al. 2000). Moreover, increased production of ROS and oxidative stress are connected to TGF- $\beta 1$ activation and production, indicating that they are key to the fibrotic process (Barnes and Gorin 2011; Radwan et al. 2012). 


\section{TGF- $\beta 1$ is involved in ROS production}

In various cell types, ROS formation has been shown to be enhanced in response to TGF- $\beta 1$. This process appears to be predominantly a consequence of the TGF- $\beta 1$ mediated induction of NOX4 expression and its subsequent increased activity (Cucoranu et al. 2005; Sturrock et al. 2006; Carmona-Cuenca et al. 2008; Boudreau et al. 2012). Likewise, NOX4 is selectively up-regulated in the lungs of patients with idiopathic pulmonary fibrosis and is associated with endothelial cell dysfunction and hypoxia, two processes that can foster the further up-regulation of NOX4 expression (Diebold et al. 2010a, 2010b). In addition, short interfering RNA (siRNA)-mediated NOX4 knockdown inhibits TGF- $\beta 1$-mediated pro-fibrotic responses and ECM deposition in the lungs of mice (Hecker et al. 2009). Further, NOX4 knockout mice are more protected against bleomycin-induced acute lung injury and the onset of fibrosis (Carnesecchi et al. 2011) than NOX2 knockout mice (Manoury et al. 2005). In agreement with this, the use of a low-molecular-weight NOX4 inhibitor in mice attenuates the bleomycininduced pulmonary fibrosis (Jarman et al. 2014). In addition, NOX4 has also been found to be increased in patients with hepatitis $\mathrm{C}$ virus ( $\mathrm{HCV}$ )-associated liver fibrosis and in patients with non-alcoholic steatohepatitis (Bettaieb et al. 2015). Furthermore, hepatic stellate cells (HSCs), which have a key role during liver fibrosis, induce NOX4-dependent ROS formation upon stimulation with TGF- $\beta 1$ (Proell et al. 2007) and the down-regulation of NOX4 by siRNA or the absence of NOX4 in mice inhibits the TGF- $\beta$-induced fibrotic process (Sancho et al. 2012). Although these studies indicate a dominant role of NOX4 in fibrosis, other investigations also indicate roles of NOX1 and NOX2 (Imura et al. 1992; Aram et al. 2008, 2009; J.X. Jiang et al. 2010; Paik et al. 2011).

In agreement with the consideration that fibrosis is an age-related disease, NOX4 and its role in fibrosis have also been found to be connected with aging. In particular, NOX4 appears to have different roles in young and in aged mice; in young mice, NOX4 stimulates myofibroblast differentiation and wound healing but, in aged mice, it induces fibrosis (Hecker et al. 2009, 2014; Thannickal 2010). The fibrotic response in aged animals might be the result of a reduced antioxidant response. Accordingly, the ratio between NOX4 and the antioxidant transcription factor NRF2 (nuclear factor erythroid 2related factor 2; see below) has been proposed to be crucial for the development of fibrosis and apoptosisresistant myofibroblasts in aged mice (Thannickal 2010). Together, TGF- $\beta 1$-driven ROS formation involving NOX4 appears to play an important role in the pathogenesis of fibrosis, in particular, in elderly subjects.

\section{TGF- $\beta 1$ is a negative regulator of the antioxidative response}

The increase in ROS levels in response to TGF- $\beta 1$ may also be a result of the suppressed expression of several antioxidant enzymes. As a result, the formation and removal of ROS are no longer balanced leading to oxidative stress. A number of exogenous substances and endogenous molecules, among them glutathione (GSH) and several enzymes, such as superoxide dismutases (SODs), glutathione peroxidases (GPXs) and catalase (CTL) represent major players in the antioxidant defence system (Samoylenko et al. 2013; Fig. 3).

The ubiquitously present reduced three-residue peptide GSH ( $\gamma$-L-glutamyl-L-cysteinyl glycine) acts as a major cellular antioxidant (Foyer and Noctor 2011). It is present at a relatively high concentration $(1-10 \mathrm{mM})$ and is able to donate an electron, a process upon which two molecules of GSH form oxidized glutathione (GSSG). This process is reversible and is carried out by the enzyme glutathione reductase (Fig. 3). Although GSH can directly react with $\mathrm{O}_{2}{ }^{-}$and some other ROS, its indirect ROS-scavenging functions are more important (Winterbourn and Metodiewa 1994; Winterbourn 2008; Blokhina and Fagerstedt 2010). In particular, GSH can regenerate other antioxidants, e.g., it can reduce $\alpha$-tocopherol radicals and semihydroascorbate radicals (Blokhina and Fagerstedt 2010) or, together with GPXs, can convert hydrogen peroxide into water. Further, GSH acts together with glutaredoxins and glutathione $\mathrm{S}$ transferase (GST) to detoxify reactive electrophilic compounds, which are products of oxidative stress and often constituents of environmental toxins (Fernandes and Holmgren 2004).

Patients with fibrotic diseases such as liver cirrhosis, viral hepatitis, chronic obstructive lung diseases and asbestosis display reduced GSH levels, which may contribute to increased ROS levels (Gao and Bataller 2011; Geybels et al. 2013; Choi et al. 2014). One factor that might be of importance in the pathogenic process of fibrosis is chronic alcohol abuse, which is well known as being a major reason for chronic liver disease and cirrhosis, whereby it can cause an 80-90\% depletion of GSH in the liver (Bianchi et al. 2000). However, GSH restriction because of alcohol consumption appears not to be restricted to liver tissue, as it can also occur in the lungs (Bianchi et al. 2000). A major reason for the GSH deficiency appears to be decreased GSH generation triggered by TGF- $\beta 1$, which affects the expression of one of the gamma-glutamylcysteine synthetase (gamma-GCS) subunits. Gamma-GCS is the ratecontrolling enzyme of GSH synthesis (Arsalane et al. 1997; Ramani et al. 2012) and consists in the regulatory light (gamma-GCSl) subunit and the catalytic heavy (gammaGCSh) subunit. Of these two subunits, TGF- $\beta 1$ has been shown to down-regulate the expression of gamma-GCSh in the fibrotic areas of interstitial pneumonia (Tiitto et al. 2004) and in human lung alveolar epithelial cells (Liu et al. 2012). 


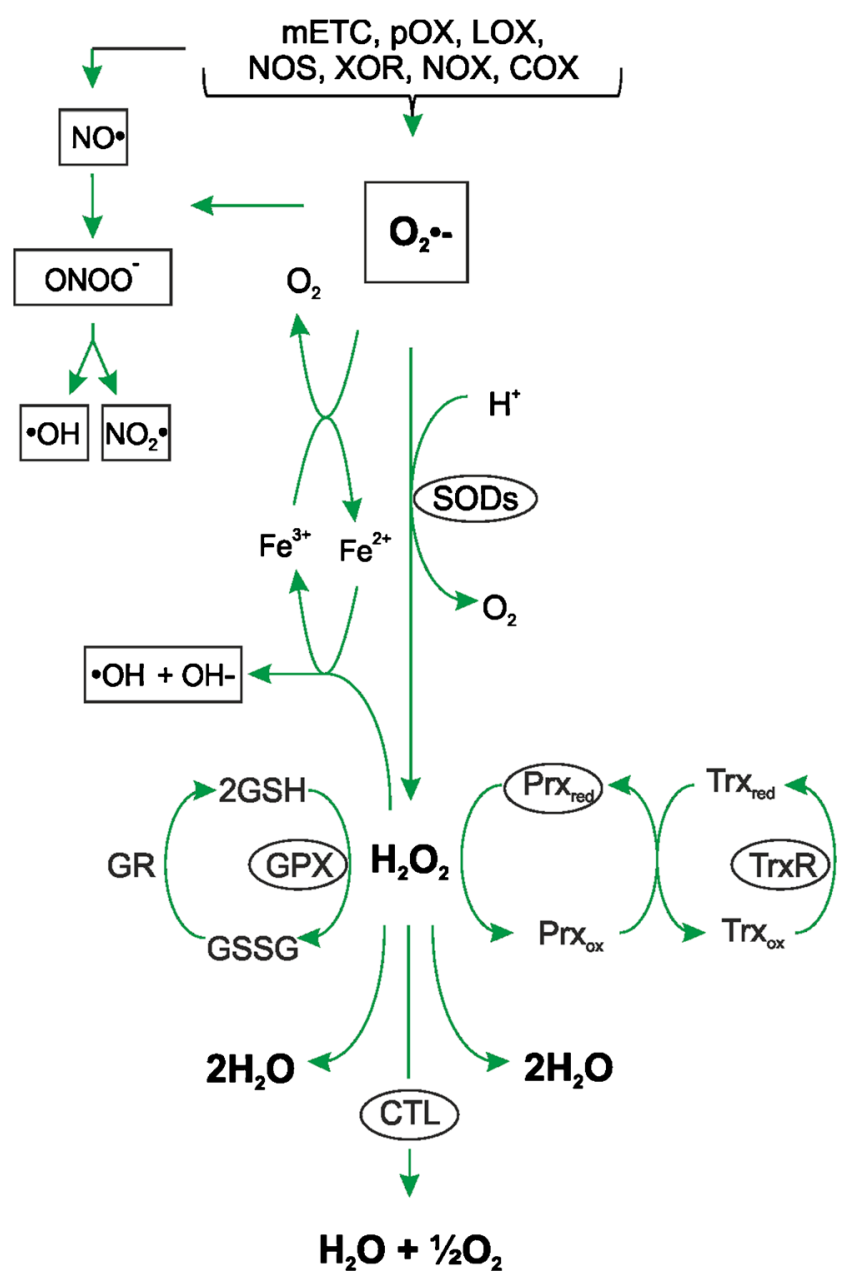

Fig. 3 Various antioxidant enzymes act on ROS. Superoxide $\left(\mathrm{O}_{2}{ }^{-}\right)$is a major ROS and can be produced by various enzymes; it serves as the main precursor for the production of other ROS and, upon reaction with nitric oxide $(\mathrm{NO})$, it gives rise to peroxynitrite formation $\left(\mathrm{ONOO}^{-}\right)$. Antioxidant enzymes (ellipsoids) such as superoxide dismutase (SOD) are able to convert $\mathrm{O}_{2}{ }^{--}$to hydrogen peroxide $\left(\mathrm{H}_{2} \mathrm{O}_{2}\right)$, which can be neutralized through the action of glutathione peroxidases $(G P X)$, peroxiredoxins $(\operatorname{Prx})$ or catalase $(C T L)$. Non-neutralized hydrogen peroxide may be converted in the presence of $\mathrm{Fe}^{2+}$ into hydroxyl radicals $\left.{ }^{\circ} \mathrm{OH}\right)$ and hydroxyl anions $(\mathrm{OH})$ in the Fenton reaction $(m E T C$ itochondrial electron transport chain, LOX lipoxygenase, pOX peroxidase, $N O X$ NADPH oxidase, $X O R$ xanthine oxidoreductase, $C O X$ cyclooxygenase, $\mathrm{NOS}$ nitric oxide synthase, $\mathrm{NO}_{2}{ }^{\bullet}$ nitrogen dioxide, $\mathrm{Tr} x$ thioredoxin, $\operatorname{Tr} x R$ thioredoxin reductase, GR glutathione reductase, GSH glutathione, GSSG oxidized glutathione)

The reduction of gamma-GCSh expression and GSH generation in response to TGF- $\beta 1$ is also in agreement with the increased protein oxidation and lipid peroxidation in mice with lung fibrosis (Liu et al. 2012). All in all, TGF- $\beta 1$ mediated reduction in GSH production might contribute to oxidative stress during the fibrotic process.

As mentioned above, GSH can act together with the glutaredoxins (Grxs), which function as thiol-disulphide oxidoreductases. In connection with this, TGF- $\beta 1$ has been shown to reduce Grx1 expression, again indicating that
GSH-driven processes are of importance in fibrosis (Peltoniemi et al. 2006; Harju et al. 2007).

Another family of enzymes with antioxidant functions are the SODs, which catalyse the conversion of $\mathrm{O}_{2}{ }^{-}$into hydrogen peroxidase and $\mathrm{O}_{2}$. Mammals possess three SODs: cytosolic (SOD1), mitochondrial (SOD2) and extracellular (SOD3) variants. Although the generated hydrogen peroxidase can be converted into oxygen and water by catalase (Samoylenko et al. 2013; McCord and Fridovich 2014), it appears that peroxiredoxins (Prxs) are more important, since they react with hydrogen peroxidase at an exceptionally high rate (Wood et al. 2003; Fig. 3). In particular, Prx2 is considered to trap almost all hydrogen peroxidase in vivo (Winterbourn 2008) as a result of its high abundance and reaction rate. Moreover, Prx members not only react with hydrogen peroxidase, but also with peroxynitrite and other organic hydroperoxides. Importantly, the various Prx members are localized in different cellular compartments, with Prx1, 2 and 4 occurring mainly in the cytoplasm and nucleus. In addition, Prx 1 can also be found in mitochondria and peroxisomes, whereas Prx 4 has been located in lysosomes (Oberley et al. 2001; Immenschuh et al. 2003; Go and Jones 2010). Prx 3 is present in mitochondria, like Prx 5 , which can also be found in the cytoplasm, nucleus and peroxisomes (Seo et al. 2000). Once oxidized, Prx molecules are reduced by thioredoxins (Trxs). The Trx proteins themselves are subject to oxidation-reduction reactions, whereby various stimuli can contribute to their oxidation and thioredoxin reductase (TrxR) mediates their NADPH-dependent reduction (Holmgren et al. 2005; Fig. 3). Again, these systems are compartmentalized, with Trx1 and TrxR1 in the cytoplasm and nucleus and Trx2 and TrxR2 in the mitochondria (Oberley et al. 2001; Go and Jones 2010).

In addition to the Prx members, GPXs are also able to reduce peroxides in various compartments. The ubiquitous member is GPX1, which reduces peroxides mainly in the cytosol, mitochondria and peroxisomes. GPX2 acts in epithelia and its highest levels are found in the intestine (Lubos et al. 2011). Another variant is represented by the secreted GPX3, which is found predominantly in lung and kidney and protects against peroxides arising from outside the cell (Lubos et al. 2011). Three isoforms of GPX4, namely the cytosolic (cGPX4), mitochondrial (m-GPX4) and nuclear (n-GPX4) isoforms (Nomura et al. 2000; Imai and Nakagawa 2003), which are derived from a single gene, have been identified so far. In addition to hydrogen peroxide, GPX4 substrates include derivatives of cholesterol and cholesteryl esters and thymine hydroperoxide (Imai and Nakagawa 2003).

The usefulness of having several systems for hydrogen peroxide conversion is mainly for preventing iron-catalyzed Fenton reactions and the subsequent generation of highly reactive hydroxyl radicals $(\cdot \mathrm{OH}$; Fig. 3). In addition, iron-binding proteins, such as ferritin and transferrin, which sequester 
free iron, also contribute to this effect. Further, so-called "dietary micronutrients" such as vitamin C, vitamin E and selenium also participate in the antioxidative process (Samoylenko et al. 2013).

Interestingly, the roles of the antioxidant enzymes during fibrosis are not yet well known. However, TGF- $\beta 1$ appears to act as a negative regulator and inhibits mRNA expression and the activities of GPX1 and CTL in a hamster pancreatic betacell line (HIT). Concomitantly, an increase in ROS levels and oxidized proteins can be detected (Islam et al. 1997). In addition, TGF- $\beta 1$ also decreases SOD1, SOD2, CTL and GST expression and increases cellular ROS levels in cultured rat hepatocytes and airway smooth muscle cells (Kayanoki et al. 1994; Islam et al. 1997; Michaeloudes et al. 2011).

Together, the fibrotic action of TGF- $\beta 1$ appears to be coupled to the suppressed expression of antioxidant enzymes. This subsequently leads to the increased production of ROS because of the prevailing action of ROS-generating systems.

\section{Fibrosis and NRF2 signalling}

The transcription factor NRF2 and its binding partner Keap1 (Kelch-like ECH-associated protein 1) regulate the transcription of various antioxidant enzymes (Hayes and Dinkova-Kostova 2014; Levonen et al. 2014). In the absence of ROS, Keap1 is bound to NRF2 and promotes its proteasomal degradation. The sulphhydryl groups at the cysteine residues in Keap1, with Cys151 as the most critical, are able to mediate redox sensitivity (Kensler et al. 2007; Hayes and Dinkova-Kostova 2014). They become oxidized upon an increase in ROS and Keap1 loses its binding to NRF2. Moreover, ROS cause the dephosphorylation of Keap1 at Tyr141, an event that promotes Keap1 degradation (Jain et al. 2008). As a consequence, NRF2 can no longer be degraded and is transported to the nucleus, where its presence is promoted because of the inability of the nuclear export protein CRM1 to bind the Cys183-oxidized NRF2. In the nucleus, NRF2 heterodimerizes with a small Maf protein and activates genes whose products are involved in the antioxidant response (Kensler et al. 2007; Hayes and Dinkova-Kostova 2014).

Several investigators have pointed out that NRF2 signalling is of importance in the pathogenesis of fibrosis. Indeed, $\mathrm{NRF}^{-/-}$mice have been found to be more prone to chemically induced oxidative stress than wild-type mice (Aleksunes and Manautou 2007; Liu et al. 2013). This is particularly evident in the liver, where NRF2 protects mice from carbontetrachloride-induced hepatic fibrosis (Xu et al. 2008) or fibrosis when fed a methionine- and choline-deficient diet (Chowdhry et al. 2010; Sugimoto et al. 2010; Zhang et al. 2010; Okada et al. 2012). In addition, the response to high- fat diets or chronic alcohol abuse appears to involve the suppression of NRF2. Indeed, the onset of bleomycin-induced lung fibrosis in mice has been found to be primed by chronic alcohol abuse; the priming effect is considered to be the result of the reduced expression of the NRF2-dependent genes for GST theta 2 and the catalytic subunit of glutamate-cysteine ligase and of the increased expression of TGF- $\beta 1$ (Sueblinvong et al. 2014a). The increased TGF- $\beta 1$ expression upon alcohol ingestion in this model has subsequently been shown to be the dominant modulator, since the blocking of the TGF- $\beta 1$ signal attenuates the alcohol-induced suppression of NRF2 (Sueblinvong et al. 2014b). Moreover, and in agreement with fibrosis being an age-related disorder, NRF2mediated protection against chemically induced fibrosis has been found to be less efficient with aging (Aravinthan et al. 2013).

The NRF2/Keap1 system is also subject to further modulation by other regulatory cascades. For instance, the selenoprotein TrxR1 has been found to regulate NRF2; consequently, a deficiency of selenium and the concomitant loss of TrxR1 activity not only affect NRF2 but are also combined with the induction of NOX activity and oxidative stress (Cebula et al. 2015). Moreover, the transcription factor Krüppel-like factor 9 (Klf9) can be induced by ROS via NRF2. This is an important aspect of the pathogenesis of fibrosis, since Klf9 has been shown to increase ROS in vitro and in vivo in mice and to promote bleomycin-induced pulmonary fibrosis (Zucker et al. 2014). Thus, the induction of Klf9 by NRF2 results in a critical feed-forward response that might promote ROS formation and fibrosis.

A number of substances naturally occurring in plants, such as quercetin, genistein and curcumin, are considered to be health-beneficial. They are, among environmental agents such as paraquat, metals and endogenous substances such as hydrogen peroxide, NO and 4hydroxynonenal, known to be NRF2 activators (Ma and He 2012). Although this implies that the induction of NRF2 is of therapeutic benefit, NRF2 activation attributable to Keap1 absence in mice has been found to cause death shortly after birth, although the lethal phenotype can be rescued in Keap1/NRF2 double-knockout mice (Wakabayashi et al. 2003). Another study has shown that the constitutive activation of NRF2 promotes tumour survival (T. Jiang et al. 2010). These findings indicate that chronic or excessive NRF2 activation negatively affects cellular behaviour and normal life span.

Overall, the NRF2 pathway appears to be critically involved in the ROS-mediated regulation of fibrosis, especially in connection with its inactivation in response to TGF- $\beta 1$. However, the cross-talk and feed-forward and feedback mechanisms impacting the NRF2 system are not yet completely understood and thus remain to be resolved in order to gain a more complete picture of its role in fibrosis. 


\section{ROS activate TGF- $\beta$}

Like many growth factors and hormones, TGF- $\beta$ needs to be activated. Normally, TGF- $\beta$ is bound to two polypeptides: a latent TGF- $\beta$-binding protein (LTBP) and a latencyassociated peptide (LAP). Together, they form an inactive, so-called latent TGF- $\beta$ complex. To become active, TGF- $\beta$ needs to be released from this complex (Fig. 4). This can be achieved via serum proteases such as plasmin, a number of matrix metalloproteases and thrombospondin-1 (Shi et al. 2011; Robertson et al. 2015). Furthermore, integrins, $\mathrm{pH}$ and ROS are able to activate TGF- $\beta$ (Lyons et al. 1988; Munger et al. 1998; Jobling et al. 2006), although whether this activation occurs directly or indirectly via integrin-, $\mathrm{pH}$ - or ROSmediated activation of proteases is not resolved.

With respect to ROS, the activation of TGF- $\beta 1$ appears to be direct, since ROS generated in a cell-free system by ionizing radiation or metal ion-catalyzed ascorbate reactions in solution can activate recombinant latent TGF- $\beta 1$ (Jobling et al. 2006). In particular, TGF- $\beta 1$ activation in response to metal ion-catalyzed ascorbate oxidation is very efficient and has been shown to depend on transition metal ions and ascorbate. Further, the ROS-dependent activation occurs only with TGF- $\beta 1$ and not the other isoforms; this has been found to be attributable to ROS-mediated oxidation of the LAP-beta1 protein at methionine 253 (Jobling et al. 2006). All in all, enhanced ROS production can be crucial for the activation of TGF- $\beta 1$, indicating another causal link to fibrosis.

\section{Fibrosis and ROS are linked to hypoxia}

The fibrotic process is not only characterized by enhanced ROS levels but is also associated with hypoxia attributable to the loss of endothelial cells and the rarefication of capillaries. The reduction of endothelial cells is largely caused by endothelial-mesenchymal transition (EndoMT), a process whereby endothelial cells undergo transformation and acquire a mesenchymal (fibroblast-like) phenotype that allows these cells to migrate and to acquire invasive properties; a similar process called epithelial-mesenchymal transition (EMT) can occur with epithelial cells. Although EndoMT and EMT are usually dormant in adult organs, insults, inflammation or chronic diseases can reactivate these embryonic processes (Dimmeler and Zeiher 2004; Abraham and Varga 2005; Asada et al. 2011).

The transcription factors hypoxia-inducible factor- $1 \alpha$ (HIF-1 $\alpha$ ) and hypoxia-inducible factor-2 $\alpha$ (HIF-2 $\alpha$ ) appear

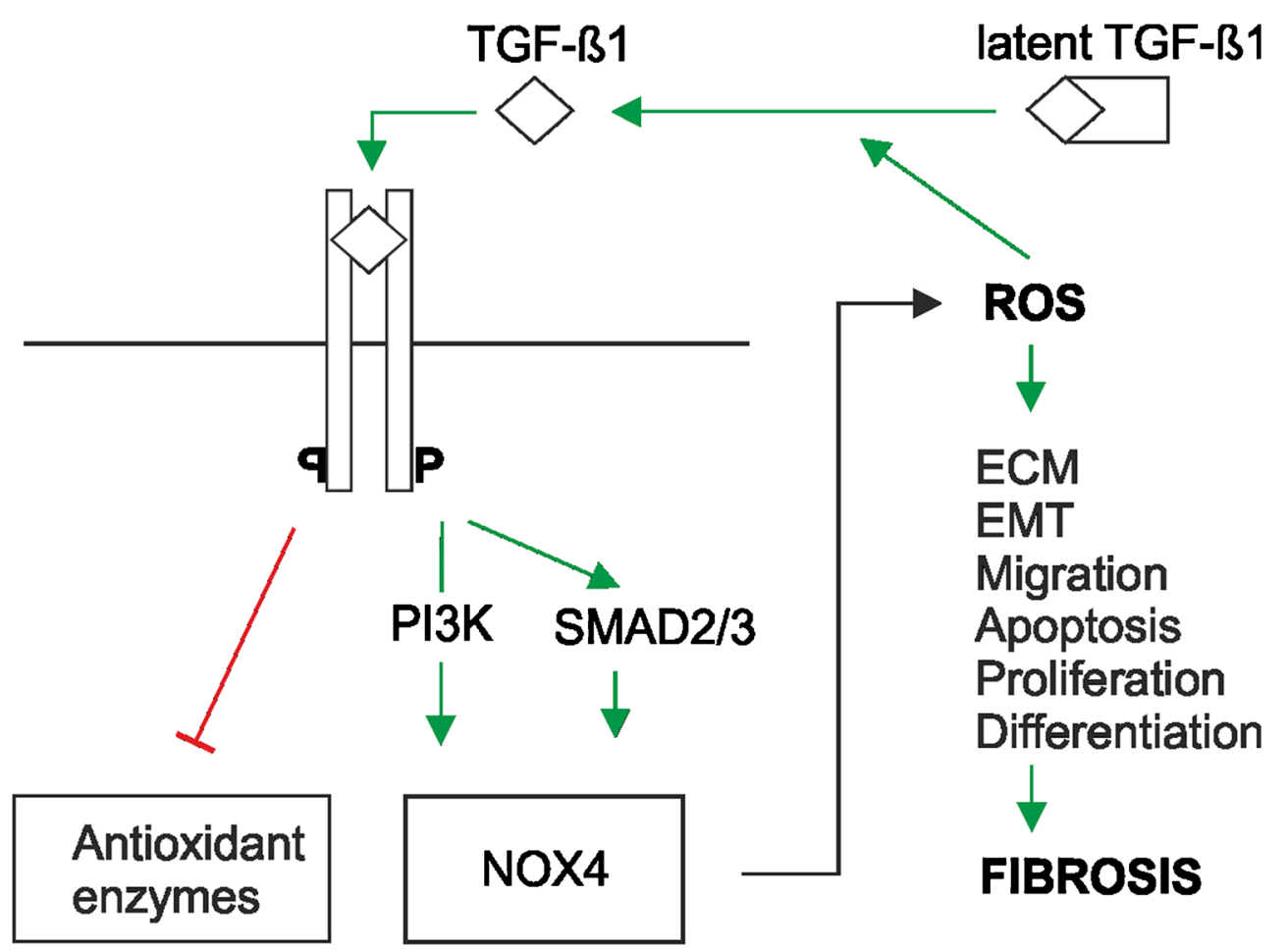

Fig. 4 ROS are involved in transforming growth factor- $\beta$ (TGF- $\beta$ )mediated fibrosis. Various cell types such as platelets, parenchymal cells and inflammatory cells (e.g., lymphocytes, macrophages) can release TGF- $\beta 1$. After conversion of the latent to the active form, TGF$\beta 1$ binds to its receptor and induces SMAD2/3 and/or phosphatidyl inositol 3-kinase $(P I 3 K)$ signalling to express various genes, among them that for NOX4. NOX4 in turn leads to ROS production. Enhanced
ROS may activate the proliferation, migration and differentiation of fibroblasts plus epithelial-to-mesenchymal transition (EMT), apoptosis of epithelial cells and/or excessive extracellular matrix $(E C M)$ deposition. In addition, TGF- $\beta 1$ contributes to ROS production by attenuating the expression of antioxidant enzymes such as glutaredoxin, catalase, glutathione peroxidase, glutathione S transferase, superoxide dismutase and the heavy subunit of gamma-glutamylcysteine synthetase 
to integrate EMT, fibrosis and the responses to various stimuli at the level of ROS signalling (Lavrovsky et al. 2000; Gorlach et al. 2015). Indeed, preclinical and clinical studies show that the fibrotic process correlates with the expression of hypoxiainducible HIF- $1 \alpha$ target genes such as those for tissueinhibitor of metalloproteinases-1, plasminogen activator inhibitor-1 (PAI-1) and connective tissue growth factor (Kaminski 2006; Tzouvelekis et al. 2007). Further, data from pulmonary fibrosis mouse models and idiopathic pulmonary fibrosis patients have revealed increased HIF- $1 \alpha$ expression in alveolar epithelial cells at an early stage of pulmonary fibrosis (Tzouvelekis et al. 2007). Moreover, TGF- $\beta 1$ and hypoxia signalling appear to undergo mutual interactions, since the major TGF- $\beta$-responsive transcription factor Smad3 can be up-regulated by hypoxia (Zhang et al. 2003) and, vice versa, the induction of type I collagen expression by TGF- $\beta 1$ can be decreased upon inhibition of HIF-1 (Basu et al. 2011).

TGF- $\beta$ and hypoxia are also drivers of EMT. Although hypoxia via HIF-1 $\alpha$ (Distler et al. 2004; Moon et al. 2009) promotes the expression of endothelial growth factors to improve the capacity to regenerate vessels (or form new ones), the link to EMT suggests that fibroblast formation and EMT will occur (Kim et al. 1998). Indeed, hypoxia and the stable expression of HIF-1 $\alpha$ have been associated with increased renal fibrosis and EMT, whereas the injection of vascular endothelial growth factor (VEGF) is beneficial in some experimental models of organ fibrosis (Corpechot et al. 2002; Yoon et al. 2005; Ioannou et al. 2013). In agreement with this evidence, the loss of HIF- $1 \alpha$ in primary renal epithelial cells reduces EMT and the targeted deletion of HIF-1 $\alpha$ in proximal tubular epithelial cells reduces tubulointerstitial fibrosis upon unilateral urethral obstruction (Higgins et al. 2007). Interestingly, the transdifferentiation of kidney tubular epithelial cells into myofibroblasts appears to be a result of HIFmediated regulation of stromal cell-derived factor 1 (SDF-1) and its receptor CXCR4 (Barriga et al. 2013), whereas a recent study of human coronary endothelial cells demonstrated that HIF-1 $\alpha$-driven expression of the transcription factor Snail is responsible for EMT (Xu et al. 2015). Together, these data suggest that hypoxia has opposing effects and, probably depending on the regenerative capacity of the injured tissue, can contribute to vessel regeneration via HIF-driven VEGF expression or to the progression of fibrosis via EMT.

\section{Fibrosis is affected by ROS via post-transcriptional and epigenetic mechanisms}

Knowledge concerning the pathogenesis of fibrosis has improved greatly, although a large number of issues are still not resolved. Among these is the often occurring inter-individual difference in the severity and progression of fibrosis. Recent advances in understanding post-transcriptional gene- regulation events, genetic variability and epigenetic phenomena have suggested that these mechanisms contribute to the variability often seen in individuals with fibrosis (Wynn 2010).

Post-transcriptional regulation is largely achieved by mRNA degradation and translational repression, processes in which microRNAs (miRNAs) play a crucial role. Indeed, several miRNAs have been found to be regulated by TGF- $\beta 1$ and shown to be regulators of pro- and anti-fibrotic processes (Pottier et al. 2014). The connection between ROS, fibrosis and miRNA expression is underlined by findings showing that TGF- $\beta 1$ regulates NOX4 expression and the NOX4dependent generation of hydrogen peroxide, which has been found to be required for TGF- $\beta$-induced myofibroblast differentiation, ECM production and contractility (Hecker et al. 2009). The expression of NOX4 and thus ROS generation can be down-regulated by the so-called "redoximiRs" miR146a and miR-25 (Cheng et al. 2013), whereas miR-135b and miR-708 can be up-regulated by hydrogen peroxide (Fig. 5). In addition, NRF2 expression can be switched off by miR153, miR-27a, miR-142-5p and miR144. The NRF2 partner Keap1 can be regulated by miR-200a, with the consequence that NRF2 is activated. Further activation of NRF2 can be achieved via miR-34a targeting sirtuin1 (Sirt1), which normally deacetylates NRF2 to promote its nuclear export (for reviews, see Cheng et al. 2013; Narasimhan et al. 2012). Another miRNA, miR-27 a/b, reduces prohibitin 1 and NRF2 (Yang et al. 2013) and leads to the appearance of nonalcoholic steatohepatitis-like symptoms and liver fibrosis. In addition, miR-433 decreases the expression of the major glutathione-synthesizing enzyme gamma-GCS (EspinosaDiez et al. 2014) and contributes to oxidative stress. Furthermore, fibrotic kidneys have been found to display a loss of miR-30e, which, if present, would counteract EMT ( L. Jiang et al. 2013). Thus, miRNAs are important molecules at the point at which ROS signalling and fibrosis converge.

Other factors concerning the dissimilarities occurring in fibrosis are epigenetic changes. These are heritable traits that involve no changes in DNA sequences but where changes in DNA methylation and post-translational modifications of histones and other chromatin-associated proteins regulate transcription (Helin and Dhanak 2013). In particular, DNA methylation can be affected by ROS; oxidatively modified bases such as 8-oxo-2'-deoxyguanosine (8-oxodG) may inhibit the methylation of adjacent cytosines (Turk et al. 1995). The methylation of cytosine at its 5-position (5-methylcytosine $[5 \mathrm{mC}])$, sometimes called the "fifth base," is associated with transcriptional silencing. As a consequence of 8-oxodGinhibited methylation, the resulting hypomethylation results in transcriptional activation, whereby cells might gain new characteristics that promote various processes, among them fibrosis. On the other hand, ROS have also been linked to hypermethylation (Franco et al. 2008) and the down- 


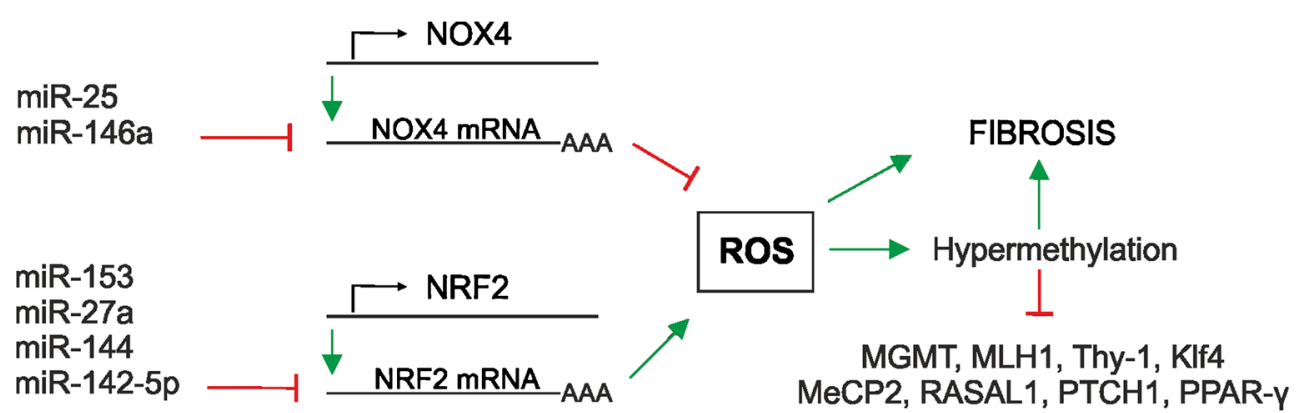

Fig. 5 Fibrosis and ROS are interconnected with microRNA (miRNA) expression and epigenetic modifications. Several miRNAs affect cellular ROS levels via the post-transcriptional degradation of NOX4 and nuclear factor erythroid 2-related factor 2 (NRF2) mRNA. In addition, epigenetically, ROS-associated DNA hypermethylation contributes to the reduced expression of various genes, among them O-6-

methylguanine-DNA methyltransferase (MGMT), mutL homologue 1 $(M L H 1)$, thymocyte differentiation antigen-1 (Thy-1), Krüppel-like factor 4 (Klf4), methyl $\mathrm{CpG}$ binding protein 2 (MeCP2), RAS protein activator 1 (RASAL1), peroxisome proliferator-activated receptor $(P P A R-\gamma)$ and patched1 $(P T C H 1)$

regulation of repair genes such as O-6-methylguanine-DNA methyltransferase and MLH1 (mutL homologue 1; Ziech et al. 2011). Further, the hypermethylation of the phosphatase and tension homologue (PTEN) favours ERK and AKT signalling, cell proliferation and migration and the promotion of liver fibrosis (Bian et al. 2012). In addition, hypoxia has been associated with changes in global DNA methylation and, in particular, HIF- $1 \alpha$ has been found directly to activate DNA methyltransferase 1 (DNMT1) and DNMT3B expression in cardiac fibroblasts. In agreement with this, the inhibition or genetic ablation of DNMT counteracts the hypoxia-induced expression of pro-fibrotic genes in cardiac tissue. Again, hypoxia-induced hypermethylation has been found in connection with the Thy-1 cell surface antigen promoter and appears to foster the development of a pro-fibrotic phenotype in human pulmonary fibroblasts (Robinson et al. 2012). Silencing of methylcytosine dioxygenase 3 has been found to contribute to bone-morphogenic-protein 7-induced reversal of kidney fibrosis attributable to 5-hydroxymethylcytosine formation and thus hypomethylation in the RAS protein activator promoter RASAL1 (Tampe et al. 2014). In addition, the hypermethylation and repression of Klf4 via Dnmt1 (Xiao et al. 2015) and the hypermethylation of methyl CpG binding protein 2 (Yang et al. 2013), RASAL1 (Tao et al. 2011), peroxisome proliferator-activated receptor (Zhao et al. 2013) and patched1 (Yang et al. 2013) also appear to promote fibrosis.

In addition to the above-mentioned factors, epigenetic modifications in antioxidant enzyme genes may also account for variations in the fibrotic process. Recent data point to the epigenetic silencing of the SOD2 gene, which may be a result of increased $\mathrm{O}_{2}{ }^{--}$levels, constituting a feed-forward mechanism promoting further epigenetic aberrancies (Hitchler et al. 2006; Teoh-Fitzgerald et al. 2012; Cyr et al. 2013). Thereby, $\mathrm{O}_{2}{ }^{\cdot-}$ serves as a starting point for the generation of other ROS, with the consequence that metabolites such as $\mathrm{NAD}(+)$, Sadenosyl methionine and 2-oxoglutarate are altered. Because these substances are critical for sirtuins, histone

methyltransferases, histone demethylases and DNA demethylases, these alterations immediately affect the epigenetic landscape (Cyr et al. 2013). Together, epigenetic aberrancies attributable to ROS might account for a number of variants seen in fibrotic phenotypes and could eventually be involved in the progression of cells from fibrotic to cancer phenotypes.

\section{Are antioxidants a treatment option in fibrosis?}

The connection of fibrosis with ROS and oxidative stress implies that supplementation with nutrients or diets with antioxidants will, in addition to disease-specific therapies and the inhibition of TGF- $\beta$ signalling, be beneficial. In general, this is not a new idea and part of a worldwide "antioxidant hype" that has been applied to other oxidative-stress-associated diseases such as cancer, type II diabetes and cardiovascular diseases (for a review, see Samoylenko et al. 2013). However, several studies have demonstrated that dietary supplementation with antioxidants does not have a positive influence but rather a negative effect on overall mortality; in particular, vitamin $\mathrm{A}, \beta$-carotene and vitamin $\mathrm{E}$ increase mortality (Bjelakovic et al. 2007). Vitamin $\mathrm{E}$ has also been linked to prostate cancer (Klein et al. 2011). With respect to fibrosis, a prospective double-blind randomized placebo-controlled trial has been carried out among a total of 49 patients with nonalcoholic steatohepatitis receiving vitamins $\mathrm{C}$ and $\mathrm{E}(1000 \mathrm{mg}$ and $1000 \mathrm{IU}$ daily for 6 months, respectively) together with a diet limited to 1600 kcalories/day. Evaluation of the histological data from 45 patients finishing the study demonstrated no statistically significant differences in inflammation/ necrosis between the vitamin group and the placebo group or within the vitamin or the placebo groups. Additionally, no significant difference in fibrosis was noted between the vitamin and the placebo groups. However, significant improvement in fibrosis was recorded within the group that 
received vitamins $\mathrm{E}$ and $\mathrm{C}$ but not in the placebo group (Harrison et al. 2003). Multicentre trials among patients suffering from idiopathic lung fibrosis have shown that antioxidant treatment has no or only a modestly beneficial effect (Demedts et al. 2005; Day 2008; Idiopathic Pulmonary Fibrosis Clinical Research Network et al. 2014). Further, vitamin supplementation has been shown to accelerate renal function decline in patients thought to have diabetic nephropathy (House et al. 2010). This lack of (or reduced) benefit not only applies to fibrosis but is also observed in cancer, type II diabetes and cardiovascular diseases and is known as the "antioxidant paradox" (Halliwell 2000; Hollman et al. 2011; Sheikh-Ali et al. 2011).

The reasons that antioxidants do not fulfil their expectations might be multiple and attributable; for example, to the wrong type/dose combinations, variations in treatment duration, poorly understood mechanisms of action and a lack of tests for compliance (for reviews, see Gorlach et al. 2015; Schmidt et al. 2015). However, recently, resveratrol, a natural antioxidant present in grapes and various berries, has been suggested as being of use in lung fibrosis, respiratory diseases such as asthma and chronic obstructive pulmonary disease. However, even if in vitro and animal data support resveratrol use, careful clinical patient characterization is needed, since resveratrol has been shown to exert opposite effects on the hypoxia-dependent expression of the breast cancer evidence marker PAI-1 in tumour vs. primary cells (Ganjam et al. 2015). Moreover, large clinical trials with resveratrol remain somewhat limited and further studies need to be performed to assess its real benefit (Conte et al. 2015). In particular, this seems to be important as regards dosage and the combination of antioxidants in the diet, since high doses of a single antioxidant in the diet have been shown to be harmful in smokers, whereas diets enriched with two antioxidants were safe in a randomised controlled trial in male smokers (Karlsen et al. 2011). Thus, antioxidant therapies for fibrosis and other diseases may still have a future but increased efforts with respect to research into ROS, antioxidants and disease pathogenesis in conjunction with large multicentre trials are required.

\section{Concluding remarks}

All in all, ROS have an important role in fibrosis, in particular, in conjunction with the TGF- $\beta 1$ signalling system. However, current knowledge represents just a basic understanding of the way that ROS contribute to fibrosis and details of the interplay with signalling pathways other than that involving TGF- $\beta 1$ are largely lacking. Although the mechanisms involved show a causative role of ROS in fibrosis, they do not allow any precise conclusions or recommendations in terms of antioxidant therapy, which itself is somewhat questionable. At the same time, this lack of knowledge increases the demand for further understanding to be gained about the mechanisms linking the dynamics of ROS and antioxidant action and about the pathogenesis of fibrosis and its future therapies.

Acknowledgments The authors are grateful to all researchers who contributed to the field and apologize to all those whose work could not be cited because of space limitations.

Open Access This article is distributed under the terms of the Creative Commons Attribution 4.0 International License (http://creativecommons.org/ licenses/by/4.0/), which permits unrestricted use, distribution, and reproduction in any medium, provided you give appropriate credit to the original author(s) and the source, provide a link to the Creative Commons license, and indicate if changes were made.

\section{References}

Abraham DJ, Varga J (2005) Scleroderma: from cell and molecular mechanisms to disease models. Trends Immunol 26:587-595

Abraham DJ, Shiwen X, Black CM, Sa S, Xu Y, Leask A (2000) Tumor necrosis factor alpha suppresses the induction of connective tissue growth factor by transforming growth factor-beta in normal and scleroderma fibroblasts. J Biol Chem 275:15220-15225

Aguirre J, Lambeth JD (2010) Nox enzymes from fungus to fly to fish and what they tell us about Nox function in mammals. Free Radic Biol Med 49:1342-1353

Akram KM, Samad S, Spiteri M, Forsyth NR (2013) Mesenchymal stem cell therapy and lung diseases. Adv Biochem Eng Biotechnol 130:105-129

Aleksunes LM, Manautou JE (2007) Emerging role of Nrf2 in protecting against hepatic and gastrointestinal. Dis Toxicol Pathol 35:459-473

Aragno M, Mastrocola R, Alloatti G, Vercellinatto I, Bardini P, Geuna S, Catalano MG, Danni O, Boccuzzi G (2008) Oxidative stress triggers cardiac fibrosis in the heart of diabetic rats. Endocrinology 149:380-388

Aram G, Potter JJ, Liu X, Torbenson MS, Mezey E (2008) Lack of inducible nitric oxide synthase leads to increased hepatic apoptosis and decreased fibrosis in mice after chronic carbon tetrachloride administration.Hepatology 47:2051-2058

Aram G, Potter JJ, Liu X, Wang L, Torbenson MS, Mezey E (2009) Deficiency of nicotinamide adenine dinucleotide phosphate, reduced form oxidase enhances hepatocellular injury but attenuates fibrosis after chronic carbon tetrachloride administration. Hepatology 49:911-919

Aravinthan A, Scarpini C, Tachtatzis P, Verma S, Penrhyn-Lowe S, Harvey R, Davies SE, Allison M, Coleman N, Alexander G (2013) Hepatocyte senescence predicts progression in non-alcoholrelated fatty liver disease. J Hepatol 58:549-556

Arsalane K, Dubois CM, Muanza T, Begin R, Boudreau F, Asselin C, Cantin AM (1997) Transforming growth factor-betal is a potent inhibitor of glutathione synthesis in the lung epithelial cell line A549: transcriptional effect on the GSH rate-limiting enzyme gammaglutamylcysteine synthetase. Am J Respir Cell Mol Biol 17:599-607

Asada N, Takase M, Nakamura J, Oguchi A, Asada M, Suzuki N, Yamamura K, Nagoshi N, Shibata S, Rao TN, Fehling HJ, Fukatsu A, Minegishi N, Kita T, Kimura T, Okano H, Yamamoto M, Yanagita M (2011) Dysfunction of fibroblasts of extrarenal origin underlies renal fibrosis and renal anemia in mice. J Clin Invest 121:3981-3990

Babalola O, Mamalis A, Lev-Tov H, Jagdeo J (2014) NADPH oxidase enzymes in skin fibrosis: molecular targets and therapeutic agents. Arch Dermatol Res 306:313-330

Badid N, Ahmed FZ, Merzouk H, Belbraouet S, Mokhtari N, Merzouk SA, Benhabib R, Hamzaoui D, Narce M (2010) Oxidant/antioxidant status, lipids and hormonal profile in overweight women with breast cancer. Pathol Oncol Res 16:159-167 
Barnes JL, Gorin Y (2011) Myofibroblast differentiation during fibrosis: role of NAD(P)H oxidases. Kidney Int 79:944-956

Barriga EH, Maxwell PH, Reyes AE, Mayor R (2013) The hypoxia factor Hif-1alpha controls neural crest chemotaxis and epithelial to mesenchymal transition. J Cell Biol 201:759-776

Basu RK, Hubchak S, Hayashida T, Runyan CE, Schumacker PT, Schnaper HW (2011) Interdependence of HIF-1alpha and TGF-beta/Smad3 signaling in normoxic and hypoxic renal epithelial cell collagen expression. Am J Physiol Renal Physiol 300:F898-F905

BelAiba RS, Djordjevic T, Petry A, Diemer K, Bonello S, Banfi B, Hess J, Pogrebniak A, Bickel C, Gorlach A (2007) NOX5 variants are functionally active in endothelial cells. Free Radic Biol Med 42:446-459

Bernard K, Hecker L, Luckhardt TR, Cheng G, Thannickal VJ (2014) NADPH oxidases in lung health and disease. Antioxid Redox Signal 20:2838-2853

Bettaieb A, Jiang JX, Sasaki Y, Chao TI, Kiss Z, Chen X, Tian J, Katsuyama M, Yabe-Nishimura C, Xi Y, Szyndralewiez C, Schroder K, Shah A, Brandes RP, Haj FG, Torok NJ (2015) Hepatocyte nicotinamide adenine dinucleotide phosphate reduced oxidase 4 regulates stress signaling, fibrosis, and insulin sensitivity during development of steatohepatitis in mice. Gastroenterology 149:468-480

Bian EB, Huang C, Ma TT, Tao H, Zhang H, Cheng C, Lv XW, Li J (2012) DNMT1-mediated PTEN hypermethylation confers hepatic stellate cell activation and liver fibrogenesis in rats. Toxicol Appl Pharmacol 264:13-22

Bianchi G, Brizi M, Rossi B, Ronchi M, Grossi G, Marchesini G (2000) Synthesis of glutathione in response to methionine load in control subjects and in patients with cirrhosis. Metabolism 49:1434-1439

Bjelakovic G, Nikolova D, Gluud LL, Simonetti RG, Gluud C (2007) Mortality in randomized trials of antioxidant supplements for primary and secondary prevention: systematic review and meta-analysis. JAMA 297:842-857

Blokhina O, Fagerstedt KV (2010) Oxidative metabolism, ROS and NO under oxygen deprivation. Plant Physiol Biochem 48:359-373

Boin F, Hummers LK (2008) Scleroderma-like fibrosing disorders. Rheum Dis Clin North Am 34:199-220

Boudreau HE, Casterline BW, Rada B, Korzeniowska A, Leto TL (2012) Nox4 involvement in TGF-beta and SMAD3-driven induction of the epithelial-to-mesenchymal transition and migration of breast epithelial cells. Free Radic Biol Med 53:1489-1499

Brown DI, Griendling KK (2009) Nox proteins in signal transduction. Free Radic Biol Med 47:1239-1253

Bucala R, Spiegel LA, Chesney J, Hogan M, Cerami A (1994) Circulating fibrocytes define a new leukocyte subpopulation that mediates tissue repair. Mol Med 1:71-81

Carmona-Cuenca I, Roncero C, Sancho P, Caja L, Fausto N, Fernandez M (2008) Upregulation of the NADPH oxidase NOX4 by TGF-beta in hepatocytes is required for its pro-apoptotic activity. $\mathrm{J}$ Hepatol 49: 965-976

Carnesecchi S, Deffert C, Donati Y, Basset O, Hinz B, Preynat-Seauve O, Guichard C, Arbiser JL, Banfi B, Pache JC, Barazzone-Argiroffo C, Krause KH (2011) A key role for NOX4 in epithelial cell death during development of lung fibrosis. Antioxid Redox Signal 15: 607-619

Cebula M, Schmidt EE, Arner ES (2015) TrxR1 as a potent regulator of the Nrf2-Keap1 response system. Antioxid Redox Signal 23:823-853

Cheng X, Ku CH, Siow RC (2013) Regulation of the Nrf2 antioxidant pathway by microRNAs: new players in micromanaging redox homeostasis. Free Radic Biol Med 64:4-11

Choi J, Corder NL, Koduru B, Wang Y (2014) Oxidative stress and hepatic Nox proteins in chronic hepatitis $\mathrm{C}$ and hepatocellular carcinoma. Free Radic Biol Med 72:267-284

Chowdhry S, Nazmy MH, Meakin PJ, Dinkova-Kostova AT, Walsh SV, Tsujita T, Dillon JF, Ashford ML, Hayes JD (2010) Loss of Nrf2 markedly exacerbates nonalcoholic steatohepatitis. Free Radic Biol Med 48:357-371

Conte E, Fagone E, Fruciano M, Gili E, Iemmolo M, Vancheri C (2015) Anti-inflammatory and antifibrotic effects of resveratrol in the lung. Histol Histopathol 30:523-529

Corpechot C, Barbu V, Wendum D, Kinnman N, Rey C, Poupon R, Housset C, Rosmorduc O (2002) Hypoxia-induced VEGF and collagen I expressions are associated with angiogenesis and fibrogenesis in experimental cirrhosis. Hepatology 35:1010-1021

Cucoranu I, Clempus R, Dikalova A, Phelan PJ, Ariyan S, Dikalov S (2005) NAD(P)H oxidase 4 mediates transforming growth factorbeta1-induced differentiation of cardiac fibroblasts into myofibroblasts. Circ Res 97:900-907

Cui W, Matsuno K, Iwata K, Ibi M, Matsumoto M, Zhang J, Zhu K, Katsuyama M, Torok NJ, Yabe-Nishimura C (2011) NOX1/ nicotinamide adenine dinucleotide phosphate, reduced form (NADPH) oxidase promotes proliferation of stellate cells and aggravates liver fibrosis induced by bile duct ligation. Hepatology 54 : 949-958

Cyr AR, Hitchler MJ, Domann FE (2013) Regulation of SOD2 in cancer by histone modifications and $\mathrm{CpG}$ methylation: closing the loop between redox biology and epigenetics. Antioxid Redox Signal 18:1946-1955

Day BJ (2008) Antioxidants as potential therapeutics for lung fibrosis. Antioxid Redox Signal 10:355-370

De Minicis S, Brenner DA (2007) NOX in liver fibrosis. Arch Biochem Biophys 462:266-272

Deffert C, Cachat J, Krause KH (2014) Phagocyte NADPH oxidase, chronic granulomatous disease and mycobacterial infections. Cell Microbiol 16:1168-1178

Dekhuijzen PN, Aben KK, Dekker I, Aarts LP, Wielders PL, van Herwaarden CL, Bast A (1996) Increased exhalation of hydrogen peroxide in patients with stable and unstable chronic obstructive pulmonary disease. Am J Respir Crit Care Med 154:813-816

Demedts M, Behr J, Buhl R, Costabel U, Dekhuijzen R, Jansen HM, MacNee W, Thomeer M, Wallaert B, Laurent F, Nicholson AG, Verbeken EK, Verschakelen J, Flower CD, Capron F, Petruzzelli S, De Vuyst P, van den Bosch JM, Rodriguez-Becerra E, Corvasce G, Lankhorst I, Sardina M, Montanari M, IFIGENIA Study Group (2005) High-dose acetylcysteine in idiopathic pulmonary fibrosis. N Engl J Med 353:2229-2242

Diebold I, Flugel D, Becht S, Belaiba RS, Bonello S, Hess J, Kietzmann T, Gorlach A (2010a) The hypoxia-inducible factor-2alpha is stabilized by oxidative stress involving NOX4. Antioxid Redox Signal 13:425-436

Diebold I, Petry A, Hess J, Gorlach A (2010b) The NADPH oxidase subunit NOX4 is a new target gene of the hypoxia-inducible factor-1. Mol Biol Cell 21:2087-2096

Dimmeler S, Zeiher AM (2004) Wanted! the best cell for cardiac regeneration. J Am Coll Cardiol 44:464-466

Distler O, Distler JH, Scheid A, Acker T, Hirth A, Rethage J, Michel BA, Gay RE, Muller-Ladner U, Matucci-Cerinic M, Plate KH, Gassmann M, Gay S (2004) Uncontrolled expression of vascular endothelial growth factor and its receptors leads to insufficient skin angiogenesis in patients with systemic sclerosis. Circ Res 95:109 116

Djamali A, Vidyasagar A, Adulla M, Hullett D, Reese S (2009) Nox-2 is a modulator of fibrogenesis in kidney allografts. Am J Transplant 9: $74-82$

Dvorak HF (1986) Tumors: wounds that do not heal. Similarities between tumor stroma generation and wound healing. N Engl J Med 315: $1650-1659$

Dvorak HF, Form DM, Manseau EJ, Smith BD (1984) Pathogenesis of desmoplasia. I. Immunofluorescence identification and localization of some structural proteins of line 1 and line 10 guinea pig tumors and of healing wounds. J Natl Cancer Inst 73:1195-1205 
Espinosa-Diez C, Fierro-Fernandez M, Sanchez-Gomez F, RodriguezPascual F, Alique M, Ruiz-Ortega M, Beraza N, Martinez-Chantar ML, Fernandez-Hernando C, Lamas S (2014) Targeting of gammaglutamyl-cysteine ligase by miR-433 reduces glutathione biosynthesis and promotes TGF-beta-dependent fibrogenesis. Antioxid Redox Signal 23:1092-1105

Fernandes AP, Holmgren A (2004) Glutaredoxins: glutathione-dependent redox enzymes with functions far beyond a simple thioredoxin backup system. Antioxid Redox Signal 6:63-74

Foyer CH, Noctor G (2011) Ascorbate and glutathione: the heart of the redox hub. Plant Physiol 155:2-18

Franco R, Schoneveld O, Georgakilas AG, Panayiotidis MI (2008) Oxidative stress, DNA methylation and carcinogenesis. Cancer Lett 266:6-11

Ganjam GK, Chi TF, Kietzmann T, Dimova EY (2015) Resveratrol: beneficial or not? Opposite effects of resveratrol on hypoxiadependent PAI-1 expression in tumour and primary cells. Thromb Haemost 115:461-463

Gao B, Bataller R (2011) Alcoholic liver disease: pathogenesis and new therapeutic targets. Gastroenterology 141:1572-1585

Geybels MS, Hutter CM, Kwon EM, Ostrander EA, Fu R, Feng Z, Stanford JL, Peters U (2013) Variation in selenoenzyme genes and prostate cancer risk and survival. Prostate 73:734-742

Go YM, Jones DP (2010) Redox control systems in the nucleus: mechanisms and functions. Antioxid Redox Signal 13:489-509

Gorlach A, Dimova EY, Petry A, Martinez-Ruiz A, Hernansanz-Agustin P, Rolo AP, Palmeira CM, Kietzmann T (2015) Reactive oxygen species, nutrition, hypoxia and diseases: problems solved? Redox Biol 6:372-385

Ha H, Lee HB (2003) Reactive oxygen species and matrix remodeling in diabetic kidney. J Am Soc Nephrol 14:S246-S249

Halliwell B (2000) The antioxidant paradox. Lancet 355:1179-1180

Harju TH, Peltoniemi MJ, Rytila PH, Soini Y, Salmenkivi KM, Board PG, Ruddock LW, Kinnula VL (2007) Glutathione S-transferase omega in the lung and sputum supernatants of COPD patients. Respir Res 8:48

Harrison SA, Torgerson S, Hayashi P, Ward J, Schenker S (2003) Vitamin $\mathrm{E}$ and vitamin $\mathrm{C}$ treatment improves fibrosis in patients with nonalcoholic steatohepatitis. Am J Gastroenterol 98:2485-2490

Hayes JD, Dinkova-Kostova AT (2014) The Nrf2 regulatory network provides an interface between redox and intermediary metabolism. Trends Biochem Sci 39:199-218

Hecker L, Vittal R, Jones T, Jagirdar R, Luckhardt TR, Horowitz JC (2009) NADPH oxidase-4 mediates myofibroblast activation and fibrogenic responses to lung injury. Nat Med 15:1077-1081

Hecker L, Jagirdar R, Jin T, Thannickal VJ (2011) Reversible differentiation of myofibroblasts by MyoD. Exp Cell Res 317:1914-1921

Hecker L, Logsdon NJ, Kurundkar D, Kurundkar A, Bernard K, Hock T, Meldrum E, Sanders YY, Thannickal VJ (2014) Reversal of persistent fibrosis in aging by targeting Nox4-Nrf2 redox imbalance. Sci Transl Med 6:231ra47

Helin K, Dhanak D (2013) Chromatin proteins and modifications as drug targets. Nature 502:480-488

Higgins DF, Kimura K, Bernhardt WM, Shrimanker N, Akai Y, Hohenstein B, Saito Y, Johnson RS, Kretzler M, Cohen CD, Eckardt KU, Iwano M, Haase VH (2007) Hypoxia promotes fibrogenesis in vivo via HIF-1 stimulation of epithelial-tomesenchymal transition. J Clin Invest 117:3810-3820

Hitchler MJ, Wikainapakul K, Yu L, Powers K, Attatippaholkun W, Domann FE (2006) Epigenetic regulation of manganese superoxide dismutase expression in human breast cancer cells. Epigenetics 1: 163-171

Hogaboam CM, Blease K, Mehrad B, Steinhauser ML, Standiford TJ, Kunkel SL, Lukacs NW (2000) Chronic airway hyperreactivity, goblet cell hyperplasia, and peribronchial fibrosis during allergic airway disease induced by Aspergillus fumigatus. Am J Pathol 156:723-732

Hollman PC, Cassidy A, Comte B, Heinonen M, Richelle M, Richling E, Serafini M, Scalbert A, Sies H, Vidry S (2011) The biological relevance of direct antioxidant effects of polyphenols for cardiovascular health in humans is not established. J Nutr 141:989S-1009S

Holmgren A, Johansson C, Berndt C, Lonn ME, Hudemann C, Lillig CH (2005) Thiol redox control via thioredoxin and glutaredoxin systems. Biochem Soc Trans 33:1375-1377

House AA, Eliasziw M, Cattran DC, Churchill DN, Oliver MJ, Fine A, Dresser GK, Spence JD (2010) Effect of B-vitamin therapy on progression of diabetic nephropathy: a randomized controlled trial. JAMA 303:1603-1609

Idiopathic Pulmonary Fibrosis Clinical Research Network, Martinez FJ, de Andrade JA, Anstrom KJ, King TE Jr, Raghu G (2014) Randomized trial of acetylcysteine in idiopathic pulmonary fibrosis. N Engl J Med 370:2093-2101

Imai H, Nakagawa Y (2003) Biological significance of phospholipid hydroperoxide glutathione peroxidase (PHGPx, GPx4) in mammalian cells. Free Radic Biol Med 34:145-169

Immenschuh S, Baumgart-Vogt E, Tan M, Iwahara S, Ramadori G, Fahimi HD (2003) Differential cellular and subcellular localization of heme-binding protein 23/peroxiredoxin I and heme oxygenase-1 in rat liver. J Histochem Cytochem 51:1621-1631

Imura Y, Stassen JM, Kurokawa T, Iwasa S, Lijnen HR, Collen D (1992) Thrombolytic and pharmacokinetic properties of an immunoconjugate of single-chain urokinase-type plasminogen activator (u-PA) and a bispecific monoclonal antibody against fibrin and against u-PA in baboons. Blood 79:2322-2329

Ioannou M, Pyrpasopoulou A, Simos G, Paraskeva E, Nikolaidou C, Venizelos I, Koukoulis G, Aslanidis S, Douma S (2013) Upregulation of VEGF expression is associated with accumulation of HIF-1alpha in the skin of naive scleroderma patients. Mod Rheumatol 23:1245-1248

Islam KN, Kayanoki Y, Kaneto H, Suzuki K, Asahi M, Fujii J, Taniguchi N (1997) TGF-betal triggers oxidative modifications and enhances apoptosis in HIT cells through accumulation of reactive oxygen species by suppression of catalase and glutathione peroxidase. Free Radic Biol Med 22:1007-1017

Jain AK, Mahajan S, Jaiswal AK (2008) Phosphorylation and dephosphorylation of tyrosine 141 regulate stability and degradation of INrf2: a novel mechanism in Nrf2 activation. J Biol Chem 283: 17712-17720

Jarman ER, Khambata VS, Cope C, Jones P, Roger J, Ye LY, Duggan N, Head D, Pearce A, Press NJ, Bellenie B, Sohal B, Jarai G (2014) An inhibitor of NADPH oxidase-4 attenuates established pulmonary fibrosis in a rodent disease model. Am J Respir Cell Mol Biol 50: $158-169$

Jiang JX, Venugopal S, Serizawa N, Chen X, Scott F, Li Y, Adamson R, Devaraj S, Shah V, Gershwin ME, Friedman SL, Török NJ (2010) Reduced nicotinamide adenine dinucleotide phosphate oxidase 2 plays a key role in stellate cell activation and liver fibrogenesis in vivo. Gastroenterology 139:1375-1384

Jiang T, Chen N, Zhao F, Wang XJ, Kong B, Zheng W, Zhang DD (2010) High levels of Nrf2 determine chemoresistance in type II endometrial cancer. Cancer Res 70:5486-5496

Jiang L, Qiu W, Zhou Y, Wen P, Fang L, Cao H, Zen K, He W, Zhang C, Dai C, Yang J (2013) A microRNA-30e/mitochondrial uncoupling protein 2 axis mediates TGF-beta1-induced tubular epithelial cell extracellular matrix production and kidney fibrosis. Kidney Int 84: 285-296

Jobling MF, Mott JD, Finnegan MT, Jurukovski V, Erickson AC, Walian PJ, Taylor SE, Ledbetter S, Lawrence CM, Rifkin DB, BarcellosHoff MH (2006) Isoform-specific activation of latent transforming growth factor beta (LTGF-beta) by reactive oxygen species. Radiat Res 166:839-848 
Kalluri R, Zeisberg M (2006) Fibroblasts in cancer. Nat Rev Cancer 6: 392-401

Kaminski N (2006) Gene expression profiling as a window into idiopathic pulmonary fibrosis pathogenesis: can we identify the right target genes? Proc Am Thorac Soc 3:339-344

Karlsen A, Svendsen M, Seljeflot I, Sommernes MA, Sexton J, Brevik A, Erlund I, Serafini M, Bastani N, Remberg SF, Borge GI, Carlsen MH, Bohn SK, Myhrstad MC, Dragsted LO, Duttaroy AK, Haffner K, Laake P, Drevon CA, Arnesen H, Collins A, Tonstad S, Blomhoff $\mathrm{R}$ (2011) Compliance, tolerability and safety of two antioxidant-rich diets: a randomised controlled trial in male smokers. Br J Nutr 106: $557-571$

Kayanoki Y, Fujii J, Suzuki K, Kawata S, Matsuzawa Y, Taniguchi N (1994) Suppression of antioxidative enzyme expression by transforming growth factor-beta 1 in rat hepatocytes. J Biol Chem 269:15488-15492

Kensler TW, Wakabayashi N, Biswal S (2007) Cell survival responses to environmental stresses via the Keap1-Nrf2-ARE pathway. Annu Rev Pharmacol Toxicol 47:89-116

Kim Y, Ratziu V, Choi SG, Lalazar A, Theiss G, Dang Q, Kim SJ, Friedman SL (1998) Transcriptional activation of transforming growth factor beta1 and its receptors by the Kruppel-like factor $\mathrm{Zf9}$ /core promoter-binding protein and Sp1. potential mechanisms for autocrine fibrogenesis in response to injury. J Biol Chem 273: 33750-33758

Klein EA, Thompson IM Jr, Tangen CM, Crowley JJ, Lucia MS, Goodman PJ, Minasian LM, Ford LG, Parnes HL, Gaziano JM, Karp DD, Lieber MM, Walther PJ, Klotz L, Parsons JK, Chin JL, Darke AK, Lippman SM, Goodman GE, Meyskens FL Jr, Baker LH (2011) Vitamin E and the risk of prostate cancer: the Selenium and Vitamin E Cancer Prevention Trial (SELECT). JAMA 306:1549_ 1556

Lavrovsky Y, Chatterjee B, Clark RA, Roy AK (2000) Role of redoxregulated transcription factors in inflammation, aging and agerelated diseases. Exp Gerontol 35:521-532

Leask A, Abraham DJ (2004) TGF-beta signaling and the fibrotic response. FASEB J 18:816-827

Leask A, Denton CP, Abraham DJ (2004) Insights into the molecular mechanism of chronic fibrosis: the role of connective tissue growth factor in scleroderma. J Invest Dermatol 122:1-6

Levonen AL, Hill BG, Kansanen E, Zhang J, Darley-Usmar VM (2014) Redox regulation of antioxidants, autophagy, and the response to stress: implications for electrophile therapeutics. Free Radic Biol Med 71:196-207

Lin SL, Kisseleva T, Brenner DA, Duffield JS (2008) Pericytes and perivascular fibroblasts are the primary source of collagenproducing cells in obstructive fibrosis of the kidney. Am J Pathol 173:1617-1627

Liu RM, Vayalil PK, Ballinger C, Dickinson DA, Huang WT, Wang S, Kavanagh TJ, Matthews QL, Postlethwait EM (2012) Transforming growth factor beta suppresses glutamate-cysteine ligase gene expression and induces oxidative stress in a lung fibrosis model. Free Radic Biol Med 53:554-563

Liu J, Wu KC, Lu YF, Ekuase E, Klaassen CD (2013) Nrf2 protection against liver injury produced by various hepatotoxicants. Oxid Med Cell Longev 2013:305861

Lubos E, Loscalzo J, Handy DE (2011) Glutathione peroxidase-1 in health and disease: from molecular mechanisms to therapeutic opportunities. Antioxid Redox Signal 15:1957-1997

Lyons RM, Keski-Oja J, Moses HL (1988) Proteolytic activation of latent transforming growth factor-beta from fibroblast-conditioned medium. J Cell Biol 106:1659-1665

Ma Q, He X (2012) Molecular basis of electrophilic and oxidative defense: promises and perils of Nrf2. Pharmacol Rev 64:1055-1081

Manoury B, Nenan S, Leclerc O, Guenon I, Boichot E, Planquois JM, Bertrand CP, Lagente V (2005) The absence of reactive oxygen species production protects mice against bleomycin-induced pulmonary fibrosis. Respir Res 6:11

Masamune A, Watanabe T, Kikuta K, Satoh K, Shimosegawa T (2007) NADPH oxidase plays a crucial role in the activation of pancreatic stellate cells. Am J Physiol Gastrointest Liver Physiol 294:G99G108

McCord JM, Fridovich I (2014) Superoxide dismutases: you've come a long way, baby. Antioxid Redox Signal 20:1548-1549

Michaeloudes C, Sukkar MB, Khorasani NM, Bhavsar PK, Chung KF (2011) TGF-beta regulates Nox4, MnSOD and catalase expression, and IL-6 release in airway smooth muscle cells. Am J Physiol Lung Cell Mol Physiol 300:L295-L304

Moon JO, Welch TP, Gonzalez FJ, Copple BL (2009) Reduced liver fibrosis in hypoxia-inducible factor-1alpha-deficient mice. Am J Physiol Gastrointest Liver Physiol 296:G582-G592

Munger JS, Harpel JG, Giancotti FG, Rifkin DB (1998) Interactions between growth factors and integrins: latent forms of transforming growth factor-beta are ligands for the integrin alphavbeta1. Mol Biol Cell 9:2627-2638

Murdoch CE, Zhang M, Cave AC, Shah AM (2006) NADPH oxidasedependent redox signalling in cardiac hypertrophy, remodelling and failure. Cardiovasc Res 71:208-215

Narasimhan M, Patel D, Vedpathak D, Rathinam M, Henderson G, Mahimainathan L (2012) Identification of novel microRNAs in post-transcriptional control of Nrf2 expression and redox homeostasis in neuronal, SH-SY5Y cells. PLoS One 7:e51111

Nauseef WM (2014) Detection of superoxide anion and hydrogen peroxide production by cellular NADPH oxidases. Biochim Biophys Acta 1840:757-767

Nomura K, Imai H, Koumura T, Kobayashi T, Nakagawa Y (2000) Mitochondrial phospholipid hydroperoxide glutathione peroxidase inhibits the release of cytochrome $\mathrm{c}$ from mitochondria by suppressing the peroxidation of cardiolipin in hypoglycaemia-induced apoptosis. Biochem J 351:183-193

Oberley TD, Verwiebe E, Zhong W, Kang SW, Rhee SG (2001) Localization of the thioredoxin system in normal rat kidney. Free Radic Biol Med 30:412-424

Okada K, Warabi E, Sugimoto H, Horie M, Tokushige K, Ueda T, Harada $\mathrm{N}$, Taguchi K, Hashimoto E, Itoh $\mathrm{K}$, Ishii T, Utsunomiya $\mathrm{H}$, Yamamoto M, Shoda J (2012) Nrf2 inhibits hepatic iron accumulation and counteracts oxidative stress-induced liver injury in nutritional steatohepatitis. J Gastroenterol 47:924-935

O’Neill S, Brault J, Stasia MJ, Knaus UG (2015) Genetic disorders coupled to ROS deficiency. Redox Biol 6:135-156

Paik YH, Iwaisako K, Seki E, Inokuchi S, Schnabl B, Osterreicher CH, Kisseleva T, Brenner DA (2011) The nicotinamide adenine dinucleotide phosphate oxidase (NOX) homologues NOX1 and NOX2/ gp91(phox) mediate hepatic fibrosis in mice. Hepatology 53: 1730-1741

Paik YH, Kim J, Aoyama T, De Minicis S, Bataller R, Brenner DA (2014) Role of NADPH oxidases in liver fibrosis. Antioxid Redox Signal 20:2854-2872

Pelclova D, Fenclova Z, Kacer P, Kuzma M, Navratil T, Lebedova J (2008) Increased 8-isoprostane, a marker of oxidative stress in exhaled breath condensate in subjects with asbestos exposure. Ind Health 46:484-489

Peltoniemi MJ, Rytila PH, Harju TH, Soini YM, Salmenkivi KM, Ruddock LW, Kinnula VL (2006) Modulation of glutaredoxin in the lung and sputum of cigarette smokers and chronic obstructive pulmonary disease. Respir Res 7:133

Petry A, Djordjevic T, Weitnauer M, Kietzmann T, Hess J, Gorlach A (2006) NOX2 and NOX4 mediate proliferative response in endothelial cells. Antioxid Redox Signal 8:1473-1484

Pilger A, Germadnik D, Schaffer A, Theiler A, Pils P, Sluka F, Winker N, Rudiger HW (2000) 8-Hydroxydeoxyguanosine in leukocyte DNA 
and urine of quartz-exposed workers and patients with silicosis. Int Arch Occup Environ Health 73:305-310

Pottier N, Cauffiez C, Perrais M, Barbry P, Mari B (2014) FibromiRs: translating molecular discoveries into new anti-fibrotic drugs. Trends Pharmacol Sci 35:119-126

Pratico D, Basili S, Vieri M, Cordova C, Violi F, Fitzgerald GA (1998) Chronic obstructive pulmonary disease is associated with an increase in urinary levels of isoprostane F2alpha-III, an index of oxidant stress. Am J Respir Crit Care Med 158:1709-1714

Proell V, Carmona-Cuenca I, Murillo MM, Huber H, Fabregat I, Mikulits W (2007) TGF-beta dependent regulation of oxygen radicals during transdifferentiation of activated hepatic stellate cells to myofibroblastoid cells. Comp Hepatol 6:1

Radwan MI, Pasha HF, Mohamed RH, Hussien HI, El-Khshab MN (2012) Influence of transforming growth factor-betal and tumor necrosis factor-alpha genes polymorphisms on the development of cirrhosis and hepatocellular carcinoma in chronic hepatitis $\mathrm{C}$ patients. Cytokine 60:271-276

Ramani K, Tomasi ML, Yang H, Ko K, Lu SC (2012) Mechanism and significance of changes in glutamate-cysteine ligase expression during hepatic fibrogenesis. J Biol Chem 287:36341-36355

Robertson IB, Horiguchi M, Zilberberg L, Dabovic B, Hadjiolova K, Rifkin DB (2015) Latent TGF- $\beta$-binding proteins. Matrix Biol 47: 44-53

Robinson CM, Neary R, Levendale A, Watson CJ, Baugh JA (2012) Hypoxia-induced DNA hypermethylation in human pulmonary fibroblasts is associated with Thy-1 promoter methylation and the development of a pro-fibrotic phenotype. Respir Res 13:74

Rockey DC, Bell PD, Hill JA (2015) Fibrosis - a common pathway to organ injury and failure. N Engl J Med 372:1138-1149

Romanelli RG, Caligiuri A, Carloni V, DeFranco R, Montalto P, Ceni E, Casini A, Gentilini P, Pinzani M (1997) Effect of pentoxifylline on the degradation of procollagen type I produced by human hepatic stellate cells in response to transforming growth factor-beta 1 . Br J Pharmacol 122:1047-1054

Ronnov-Jessen L, Petersen OW, Koteliansky VE, Bissell MJ (1995) The origin of the myofibroblasts in breast cancer. Recapitulation of tumor environment in culture unravels diversity and implicates converted fibroblasts and recruited smooth muscle cells. J Clin Invest 95:859-873

Rudolph KL, Chang S, Millard M, Schreiber-Agus N, DePinho RA (2000) Inhibition of experimental liver cirrhosis in mice by telomerase gene delivery. Science 287:1253-1258

Samoylenko A, Hossain JA, Mennerich D, Kellokumpu S, Hiltunen JK, Kietzmann T (2013) Nutritional countermeasures targeting reactive oxygen species in cancer: from mechanisms to biomarkers and clinical evidence. Antioxid Redox Signal 19:2157-2196

Sancho P, Mainez J, Crosas-Molist E, Roncero C, Fernandez-Rodriguez CM, Pinedo F (2012) NADPH oxidase NOX4 mediates stellate cell activation and hepatocyte cell death during liver fibrosis development. PLoS One 7:e45285

Schmidt HH, Stocker R, Vollbracht C, Paulsen G, Riley D, Daiber A, Cuadrado A (2015) Antioxidants in translational medicine. Antioxid Redox Signal 23:1130-1143

Sedeek M, Nasrallah R, Touyz RM, Hebert RL (2013) NADPH oxidases, reactive oxygen species, and the kidney: friend and foe. J Am Soc Nephrol 24:1512-1518

Seki S, Kitada T, Sakaguchi H (2005) Clinicopathological significance of oxidative cellular damage in non-alcoholic fatty liver diseases. Hepatol Res 33:132-134

Seo MS, Kang SW, Kim K, Baines IC, Lee TH, Rhee SG (2000) Identification of a new type of mammalian peroxiredoxin that forms an intramolecular disulfide as a reaction intermediate. J Biol Chem 275:20346-20354

Sheikh-Ali M, Chehade JM, Mooradian AD (2011) The antioxidant paradox in diabetes mellitus. Am J Ther 18:266-278
Shi M, Zhu J, Wang R, Chen X, Mi L, Walz T, Springer TA (2011) Latent TGF-beta structure and activation. Nature 474:343-349

Sirker A, Zhang M, Murdoch C, Shah AM (2007) Involvement of NADPH oxidases in cardiac remodelling and heart failure. Am J Nephrol 27:649-660

Strutz F, Okada H, Lo CW, Danoff T, Carone RL, Tomaszewski JE, Neilson EG (1995) Identification and characterization of a fibroblast marker: FSP1. J Cell Biol 130:393-405

Sturrock A, Cahill B, Norman K, Huecksteadt TP, Hill K, Sanders K (2006) Transforming growth factor-betal induces Nox4 NAD(P)H oxidase and reactive oxygen species-dependent proliferation in human pulmonary artery smooth muscle cells. Am J Physiol Lung Cell Mol Physiol 290:L661-L673

Sueblinvong V, Kerchberger VE, Saghafi R, Mills ST, Fan X, Guidot DM (2014a) Chronic alcohol ingestion primes the lung for bleomycininduced fibrosis in mice. Alcohol Clin Exp Res 38:336-343

Sueblinvong V, Tseng V, Smith T, Saghafi R, Mills ST, Neujahr DC, Guidot DM (2014b) TGFbetal mediates alcohol-induced Nrf2 suppression in lung fibroblasts. Alcohol Clin Exp Res 38:2731-2742

Sugimoto H, Okada K, Shoda J, Warabi E, Ishige K, Ueda T, Taguchi K, Yanagawa T, Nakahara A, Hyodo I, Ishii T, Yamamoto M (2010) Deletion of nuclear factor-E2-related factor-2 leads to rapid onset and progression of nutritional steatohepatitis in mice. Am J Physiol Gastrointest Liver Physiol 298:G283-G294

Tampe B, Tampe D, Muller CA, Sugimoto H, LeBleu V, Xu X, Muller GA, Zeisberg EM, Kalluri R, Zeisberg M (2014) Tet3-mediated hydroxymethylation of epigenetically silenced genes contributes to bone morphogenic protein 7-induced reversal of kidney fibrosis. J Am Soc Nephrol 25:905-912

Tao H, Huang C, Yang JJ, Ma TT, Bian EB, Zhang L, Lv XW, Jin Y, Li J (2011) MeCP2 controls the expression of RASAL1 in the hepatic fibrosis in rats. Toxicology 290:327-333

Teoh-Fitzgerald ML, Fitzgerald MP, Jensen TJ, Futscher BW, Domann FE (2012) Genetic and epigenetic inactivation of extracellular superoxide dismutase promotes an invasive phenotype in human lung cancer by disrupting ECM homeostasis. Mol Cancer Res 10:40-51

Thannickal VJ (2010) Aging, antagonistic pleiotropy and fibrotic disease. Int J Biochem Cell Biol 42:1398-1400

Tiitto LH, Peltoniemi MJ, Kaarteenaho-Wiik RL, Soini YM, Paakko PK, Sormunen RT, Kinnula VL (2004) Cell-specific regulation of gamma-glutamylcysteine synthetase in human interstitial lung diseases. Hum Pathol 35:832-839

Turk PW, Laayoun A, Smith SS, Weitzman SA (1995) DNA adduct 8hydroxyl-2'-deoxyguanosine (8-hydroxyguanine) affects function of human DNA methyltransferase. Carcinogenesis 16:1253-1255

Tzouvelekis A, Harokopos V, Paparountas T, Oikonomou N, Chatziioannou A, Vilaras G, Tsiambas E, Karameris A, Bouros D, Aidinis V (2007) Comparative expression profiling in pulmonary fibrosis suggests a role of hypoxia-inducible factor-1a in disease pathogenesis. Am J Respir Crit Care Med 176:1108-1119

Wakabayashi N, Itoh K, Wakabayashi J, Motohashi H, Noda S, Takahashi S, Imakado S, Kotsuji T, Otsuka F, Roop DR, Harada T, Engel JD, Yamamoto M (2003) Keap1-null mutation leads to postnatal lethality due to constitutive Nrf2 activation. Nat Genet 35:238-245

Winterbourn CC (2008) Reconciling the chemistry and biology of reactive oxygen species. Nat Chem Biol 4:278-286

Winterbourn CC, Metodiewa D (1994) The reaction of superoxide with reduced glutathione. Arch Biochem Biophys 314:284-290

Wood ZA, Poole LB, Karplus PA (2003) Peroxiredoxin evolution and the regulation of hydrogen peroxide signaling. Science 300:650-653

Wynn TA (2010) Fibrosis under arrest. Nat Med 16:523-525

Xiao X, Tang W, Yuan Q, Peng L, Yu P (2015) Epigenetic repression of Kruppel-like factor 4 through Dnmt1 contributes to EMT in renal fibrosis. Int J Mol Med 35:1596-1602 
Xu W, Hellerbrand C, Kohler UA, Bugnon P, Kan YW, Werner S, Beyer TA (2008) The Nrf2 transcription factor protects from toxin-induced liver injury and fibrosis. Lab Invest 88:1068-1078

Xu X, Tan X, Tampe B, Sanchez E, Zeisberg M, Zeisberg EM (2015) Snail is a direct target of HIF1a in hypoxia-induced endothelial to mesenchymal transition of human coronary endothelial cells. J Biol Chem 290:16653-16664

Yang JJ, Tao H, Huang C, Shi KH, Ma TT, Bian EB, Zhang L, Liu LP, Hu W, Lv XW, Li J (2013) DNA methylation and MeCP2 regulation of PTCH1 expression during rats hepatic fibrosis. Cell Signal 25: 1202-1211

Yoon YS, Uchida S, Masuo O, Cejna M, Park JS, Gwon HC, Kirchmair R, Bahlman F, Walter D, Curry C, Hanley A, Isner JM, Losordo DW (2005) Progressive attenuation of myocardial vascular endothelial growth factor expression is a seminal event in diabetic cardiomyopathy: restoration of microvascular homeostasis and recovery of cardiac function in diabetic cardiomyopathy after replenishment of local vascular endothelial growth factor. Circulation 111:2073-2085

Zeisberg EM, Tarnavski O, Zeisberg M, Dorfman AL, McMullen JR, Gustafsson E, Chandraker A, Yuan X, Pu WT, Roberts AB, Neilson EG, Sayegh MH, Izumo S, Kalluri R (2007) Endothelialto-mesenchymal transition contributes to cardiac fibrosis. Nat Med 13:952-961
Zhang H, Akman HO, Smith EL, Zhao J, Murphy-Ullrich JE, Batuman OA (2003) Cellular response to hypoxia involves signaling via Smad proteins. Blood 101:2253-2260

Zhang YK, Yeager RL, Tanaka Y, Klaassen CD (2010) Enhanced expression of Nrf2 in mice attenuates the fatty liver produced by a methionine- and choline-deficient diet. Toxicol Appl Pharmacol 245:326-334

Zhao Q, Fan YC, Zhao J, Gao S, Zhao ZH, Wang K (2013) DNA methylation patterns of peroxisome proliferator-activated receptor gamma gene associated with liver fibrosis and inflammation in chronic hepatitis B. J Viral Hepat 20:430-437

Zheng W (2009) Genetic polymorphisms in the transforming growth factor-beta signaling pathways and breast cancer risk and survival. Methods Mol Biol 472:265-277

Ziech D, Franco R, Pappa A, Panayiotidis MI (2011) Reactive oxygen species (ROS)-induced genetic and epigenetic alterations in human carcinogenesis. Mutat Res 711:167-173

Zucker SN, Fink EE, Bagati A, Mannava S, Bianchi-Smiraglia A, Bogner P, Wawrzyniak JA, Foley C, Leonova KI, Grimm MJ, Moparthy K, Ionov Y, Wang J, Liu S, Sexton S, Kandel ES, Bakin AV, Zhang Y, Kaminski N, Segal BH, Nikiforov MA (2014) Nrf2 amplifies oxidative stress via induction of Klf9. Mol Cell 53:916-928 